The importance of the research carried out by the CGIAR is widely recognized. After last year's system review of the organization, a panel of international experts headed by Maurice Strong, the founding executive director of the United Nations Environment Programme, concluded that investment in the CGIAR had been "the most effective use of official development assistance".

Alexander von der Osten, executive secretary of the CGIAR, says that support from countries other than Germany has remained strong. "Our overall budget has been gradually going up," he says.

He adds that the CGIAR has appealed against the cuts to both the finance minister and the overseas development minister in Germany. "But we didn't obtain anything other than good words," he says. "We need to mobilize public opinion so that people understand that this research is in the interests of northern countries," he adds.

Ironically, the cuts coincide with a recommendation by the Friedrich Ebert Stiftung (FES), a foundation closely linked with Germany's ruling Social Democrat Party, to increase funding for the CGIAR. In a report on possible benefits of genetic engineering for agriculture in developing countries, published last week, the FES concludes that "cuts in public funding of agricultural research relevant to developing countries mainly hit the poor".Quirin Schiermeier, Rex Dalton and Colin Macilwain

\title{
NSF under fire in survey of customer satisfaction
}

\section{Washington}

Officials at the US National Science Foundation (NSF) are smarting at the results of a survey released last week that places it near the bottom of a list of government services ranked according to customer satisfaction.

Of 28 other participating programmes, only the Internal Revenue Service and the Occupational Safety \& Health Administration came lower. Top of the list was the Administration for Children and Families.

The survey was sponsored by the President's Management Council and administered by the University of Michigan Business School. Replies to questions addressed to users of federal services were used to rank them on a 100 -point index.

The survey asked grant applicants how well the NSF had handled their requests. Nathaniel Pitts, director of the foundation's office of integrative activities, says its 70 per cent rejection rate partly explains its low score of 57 , compared to a mean of 68.6.

Of the 260 NSF survey respondents interviewed, 68 per cent had their grant applications rejected. But the answers to some questions in the survey have revealed weaknesses that cannot be corrected merely by raising the acceptance rate.

Respondents gave the agency a low score for the timeliness and efficiency of the proposal process. They also gave low marks to questions on the quality of peer-review and the fairness of the decision. Pitts says he is most concerned about these measures, as peer review is "the cornerstone of NSF".

$\mathrm{He}$ adds that recent changes to the peerreview process - particularly new requirements that weigh the impact of proposed research on society - may have contributed to the low score.

Jack Crow, director of the National High Magnetic Field Laboratory in Tallahassee, Florida, which has received $\$ 18.5$ million in NSF funds this year, says he is a "happy customer" of the agency. But he agrees that NSF's peer-review system could be improved.

NSF officials are to carry out a survey to explore problem areas more fully, and promise to participate in the consumer satisfaction index survey again next year. The results of the survey are available at http://www.bus.umich.edu/research/nqrc/ govt.html

Paul Smaglik

\section{Japan to bring in mandatory tests for GM foods}

Tokyo

Japan's Ministry of Health and Welfare (MHW) announced last week that tests on the potential health risks of genetically modified (GM) foods will be mandatory from April 2001. Such tests are currently carried out on a voluntary basis.

The ministry also announced that foods considered 'safe' would be labelled. But how this should be done is still under discussion, and the MHW says it is uncertain whether the labels would actually indicate safety, or whether they would take a similar approach to that announced earlier this year by the country's Ministry of Agriculture, Forestry and Fisheries (MAFF).

MAFF's draft regulations, released in August (see Nature 400, 605; 1999), require 30 food products containing GM ingredients to be labelled as such. Products with a mixture of GM and non-GM ingredients must be labelled as 'undifferentiated'.

Although the MHW hopes to include food safety in its labelling, many think that the two ministries should first unite their currently separate regulation systems.

The health ministry also intends to require more detailed tests on the possible

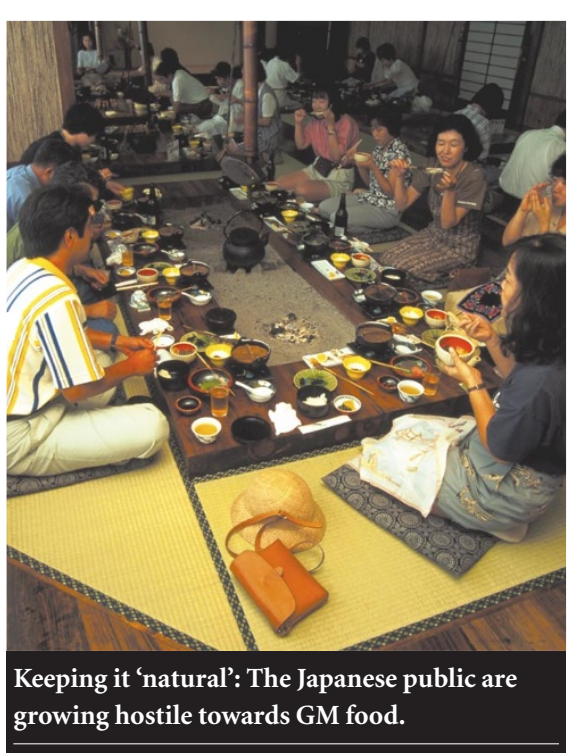

toxicity and allergenicity of GM organisms. The current guidelines give only a general outline of the safety tests. In contrast, the proposed evaluation system gives specific details of the assessment procedures.

Mandatory testing of GM products means that the evaluation of new GM foods would be halted until April 2001. This is expected to affect the commercialization of several products that have passed safety evaluation, including DuPont's soybeans enriched with oleic acid. But it may speed up the approval of GM products and improve their image with the public.

Most Japanese food manufacturers have abandoned GM ingredients. Major breweries, such as Kirin Beer, Suntory and Asahi Beer, have decided to make their beer GM-free. Ajinomoto, Japan's largest foodadditive manufacturer, last week said it was to stop using GM soybeans in its products.

Kirin Beer has also abandoned its research into GM tomatoes, although the company says that it has spent very little money on the project, which uses technology developed by Calgene, the US agribiotechnology company.

Kirin no longer plans to do research on GM food, although it will continue research into other crops. Kagome, which makes processed food, says it has no plans to commercialize its products, but will continue its research. But Japan Tobacco hopes to bring to market its GM rice, which was approved in $1998 . \quad$ Yoriko Uozum 